\title{
Application of DNA Hybridization Biosensor as a Screening Method for the Detection of Genetically Modified Food Components
}

\author{
Mariusz Tichoniuk, Marta Ligaj and Marian Filipiak*
}

Chair of Biochemistry and Microbiology, Poznan University of Economics, Al. Niepodleglosci 10, 60967 Poznan, Poland; E-mails: mariusz.tichoniuk@ae.poznan.pl; m.ligaj@ae.poznan.pl
* Author to whom correspondence should be addressed; E-mail: marian.filipiak@ae.poznan.pl; Tel.: +48618569536

Received: 29 January 2008 / Accepted: 20 March 2008 / Published: 27 March 2008

\begin{abstract}
An electrochemical biosensor for the detection of genetically modified food components is presented. The biosensor was based on 21-mer single-stranded oligonucleotide (ssDNA probe) specific to either 35S promoter or nos terminator, which are frequently present in transgenic DNA cassettes. ssDNA probe was covalently attached by 5 '-phosphate end to amino group of cysteamine self-assembled monolayer (SAM) on gold electrode surface with the use of activating reagents - water soluble 1-ethyl-3(3'dimethylaminopropyl)-carbodiimide (EDC) and N-hydroxy-sulfosuccinimide (NHS). The hybridization reaction on the electrode surface was detected via methylene blue (MB) presenting higher affinity to ssDNA probe than to DNA duplex. The electrode modification procedure was optimized using 19-mer oligoG and oligoC nucleotides. The biosensor enabled distinction between DNA samples isolated from soybean RoundupReady $^{\circledR}$ (RR soybean) and non-genetically modified soybean. The frequent introduction of investigated DNA sequences in other genetically modified organisms (GMOs) give a broad perspectives for analytical application of the biosensor.
\end{abstract}

Keywords: DNA biosensor, Self-assembled monolayer, Methylene blue, Roundup Ready soybean 


\section{Introduction}

In the past two decades there has been a considerable growth of interest in DNA biosensors due to its significant analytical properties [1-9]. One of the most popular applications of the new devices were detection and analysis of specific DNA sequences via nucleic acid hybridization [10-19]. Fast and reliable determination of nucleic acid sequence plays increasingly important role in clinical diagnosis, forensic and environmental analyses, and food safety monitoring [20-24]. Conventional methods are often time-consuming and expensive, therefore new DNA hybridization biosensors have received considerable attention [22, 23, 25]. The detection layer of the biosensor consists of short singlestranded DNA (ssDNA probe) able to form duplex with complementary target nucleic acid fragment with high efficiency and specificity. The probe is associated with a transducer translating hybridization event into a physically measurable value $[18,26,27]$. Among different combinations of ssDNA probe and transduction element the electrochemical DNA biosensors characterize very useful analytical abilities. They have relatively simple construction, are not expensive, enable appropriately sensitive and selective detection of target DNA fragments, and can be used for routine tests $[3,9,12,16,21$, 27].

The crucial aspect of the electrochemical DNA biosensor performance is the immobilization of probe on the electrode surface [15, 27-31]. The main goal of the procedure is a proper molecular orientation of the ssDNA probe and its high accessibility for the target DNA fragment. Wide range of immobilization methods was described, including physical and/or electrochemical adsorption, film entrapment, affinity binding (e.g. avidin-biotin complexation), chemisorption and covalent attachment $[12,26,27,32,33]$. The most suitable properties useful in hybridization biosensor preparation offer one-point covalent binding through molecular self assembly, due its simplicity, stability and high order of orientation of DNA probe on electrode surface [32, 34-37]. The self-assembled monolayer (SAM) created from alkane thiols on gold substrate is a very convenient linker for covalent immobilization of ssDNA probe on the electrode surface [36, 38, 39]. The efficient attachment of DNA strand on alkanethiolate monolayer are often achieved in the presence of water-soluble 1-ethyl-3(3'dimethylaminopropyl)-carbodiimide (EDC) and N-hydroxy-sulfosuccinimide (NHS) [12, 27, 34]. In this paper, ssDNA probe was immobilized on cysteamine SAM modified gold electrode surface by covalent binding with the use of both carbodiimide derivatives. Additionally the optimal time of the probe immobilization and target DNA hybridization was examined with the help of synthesized homooligomers of guanidine and cytidine (oligoG and oligoC, respectively).

The electrochemical detection of nucleic acid hybridization is based on direct measurements of electrical response of DNA strands, monitoring redox indicator compounds intercalated or electrochemically bound with DNA duplex or application of second detector probe (sandwich assays) $[12,21,26,27,33,40,41]$. In this work, methylene blue (MB), an organic dye from phenothiazine family, was used as redox indicator for DNA hybridization detection. Methylene blue interacts with the guanine bases in nucleic acid strand and provides higher accumulation rate (and therefore more intensive redox signal) on the surface of ssDNA modified electrodes than in the presence of DNA duplex [17, 38, 42-45]. Additionally Tani et al. [46] reported, that the peak potential of MB at the single-stranded nucleic acid array are obtained at potentials $c a .10-15 \mathrm{mV}$ more positive than that at double-stranded DNA arrays. 
Detection of genetically modified food components is based on the identification of specific nucleic acid fragments [47, 48]. The expression of introduced new gene(s) in GMOs are regulated by promoter and terminator. Sequences most widely used for this purpose are the $35 \mathrm{~S}$ promoter (derived from cauliflower mosaic virus) and the nos terminator (derived from Agrobacterium tumefaciens). The identification of one of these regulatory sequences in the DNA sample under examination indicates GMO presence [49]. Screening of genetically modified food compounds has developed with the progress in modern molecular techniques. Capillary electrophoresis chips, microtiter well-based hybridization assays, microarrays and real-time or competitive polymerase chain reaction (PCR) provide very promising advances in this area [24]. On the other hand, biosensors are anticipated as a leading approach in the low-cost, fast and simple GMO screening in case of routine tests, that will be available in the near future $[24,50]$. Various types of biosensors, including surface plasmon resonance sensors [51-53], quartz crystal microbalance piezoelectric sensors [54, 55] and electrochemical sensors $[50,56,57]$ can be applied for the detection of DNA fragments specific to genetically modified food compounds. Carpini et al. [56] reported enzyme-based electrochemical sensor performed with the use of oligonucleotide-modified screen-printed gold electrodes, that was employed in the detection of $35 \mathrm{~S}$ promoter sequence (amplified by PCR). Enzyme-based electrochemical detection of PCR products with the application of similar biosensor was also performed by Lucarelli et al. [57]. The sensor was used in the analysis of samples from soy and maize powders containing $1 \%$ and $5 \%$ of genetically modified product. Another electrochemical sensor designed to the detection of nos terminator was reported by Meric et al. [50]. The biosensor performance was based on immobilization of oligonucleotide probe on a screen-printed carbon electrode surface by applying a potential and application of methylene blue as a hybridization indicator. Despite of extensive research of biosensing further investigations on its application in GMO screening are still in high demand.

In this paper electrochemical DNA biosensor designed for routine screening of genetically modified food compounds is presented. The general intention was the construction of analytical device based on simple and satisfactory reliable solutions. The detection of $35 \mathrm{~S}$ promoter and nos terminator (the sequences typical for the majority of genetically modified food organisms) was performed directly, without amplification of analyzed DNA fragments with polymerase chain reaction (PCR). The samples of DNA isolated from soybean RoundupReady ${ }^{\circledR}$ (RR soybean), containing both identified sequences, and from non-genetically modified soybean (non-GM soybean) as a reference material were examined. The biosensor performance was based on modification of the gold electrode surface by ssDNA probe (specific for $35 \mathrm{~S}$ promoter or nos terminator) covalently bound with cysteamine self-assembled monolayer, which provide in a convenient way stable construction of the detection layer. The examination of hybridization reaction results was accomplished by voltammetric measurements of methylene blue (MB) accumulated on the electrode surface. In such a way, the differentiation between the DNA samples isolated from GM and non-GM soybean was accomplished without amplification of detected DNA fragments by PCR, that would have been an additional stage complicating the whole analytical procedure. The biosensor gathering uncomplicated elements in one analytical device provided simple and convenient approach for the screening of genetically modified food compounds. 


\section{Materials and Methods}

\subsection{Reagents and solutions}

Cysteamine, 1-ethyl-3(3'-dimethylaminopropyl)-carbodiimide $\quad$ (EDC), N-hydroxysulfosucciniimide (NHS), methylene blue (MB) were purchased from Sigma-Aldrich (Poznan, Poland). Sodium chloride, potassium chloride, potassium dihydrogen phosphate, disodium hydrogen phosphate were from POCh (Gliwice, Poland). All chemicals were of analytical reagent grade. Aqueous solutions were performed using deionized water.

Homooligonucleotides 19-mer oligoG and 19-mer oligoC were purchased from the Laboratory of DNA Sequencing and Oligonucleotides Synthesis, IBB PAS (Warsaw, Poland). Other oligonucleotides (21-mer probes) were synthesized in Tib Molbiol (Poznan, Poland) and had following sequences:

probe specific for 35S promoter: 5'-CCA CGT CTT CAA AGC AAG TGG probe specific for nos terminator: 5'-GCA TGA CGT TAT TTA TGA GAT

The probe sequences were chosen according to the guidelines on detection of RoundupReady ${ }^{\circledR}$ Soybean presented by Institute for Health and Consumer Protection of the Directorate General Joint Research Centre (DG JRC) [49]. The selectivity and specificity of both probes was tested in NCBI (National Center for Biotechnology Information) data base with the use of BLAST (Basic Local Alignment Search Tool) program (http://www.ncbi.nlm.nih.gov/blast/Blast.cgi). The sequences of both probes provided $100 \%$ homology to $35 \mathrm{~S}$ promoter and nos terminator respectively.

DNA from beans of genetically modified soy RoundupReady ${ }^{\circledR}$ line GTS 40-3-2 and from beans of non-GM soy was isolated and purified using Genomic Mini AX Plant DNA isolation kit (A\&A Biotechnology, Gdynia, Poland) via ion exchange columns. The purity of isolated genomic DNA was examined by measuring an absorbance of the diluted samples at the analytical wavelengths $260 \mathrm{~nm}$ (A$260)$ and $280 \mathrm{~nm}\left(\mathrm{~A}_{280}\right)$. The value of $\mathrm{A}_{260} / \mathrm{A}_{280}$ ratio was ca. 1.8 that confirmed high purity of isolated DNA. Its $50 \mu$ stock solutions in sterile water (containing $1.5 \mu \mathrm{g}$ DNA) were stored in a freezer. Before hybridization DNA solutions were diluted in $50 \mathrm{mM}$ phosphate buffer (pH 7.4) containing 0.5 $\mathrm{M} \mathrm{NaCl}$ and denatured in a nearly boiling water for 5 minutes. After heating the sample was cooled in an ice bath for $2 \mathrm{~min}$ before hybridization.

Stock solutions of oligonucleotides (5 $\mu \mathrm{M}$ for 19 -mer and $10 \mu \mathrm{M}$ for 21 -mer) were prepared in sterile water and kept frozen. Before ssDNA probe immobilization or hybridization oligonucleotides solution were diluted in appropriate buffer.

Stock solutions of MB (1.25 mM) were prepared in $50 \mathrm{mM}$ phosphate buffer $(\mathrm{pH} 7.0)$. MB solutions for investigations were prepared by dilution of stock solutions (in ratio 1:100) with $50 \mathrm{mM}$ phosphate buffer (pH 7.0) containing $5 \mathrm{mM} \mathrm{KCl}$.

A $2.5 \mathrm{mM}$ cysteamine solution, freshly prepared in deionized water, was employed for the alkanethiolate self-assembled monolayer formation on the gold electrode surface.

Other solutions used in investigations, prepared in deionized water, were: a $50 \mathrm{mM}$ phosphate buffer solution ( $\mathrm{pH}$ 7.0) for the preparation ssDNA of modified electrode; a $50 \mathrm{mM}$ phosphate buffer solution ( $\mathrm{pH} 7.0$ ) containing $5 \mathrm{mM} \mathrm{KCl}$, as supporting electrolytes; and a $50 \mathrm{mM}$ phosphate buffer ( $\mathrm{pH}$ 7.4) containing $0.5 \mathrm{M} \mathrm{NaCl}$ for preparation hybridization solutions. 


\subsection{Apparatus and electrodes}

Electrochemical measurements were carried out with potentiostat $\mu$ Autolab with GPES 4.9 software package (Eco Chemie, Utrecht, The Netherland). The voltammetric experiments were performed with three electrode system consisted of gold working electrode, $\mathrm{Ag} / \mathrm{AgCl}(3 \mathrm{M} \mathrm{KCl})$ reference electrode and platinum wire counter electrode. The surface of working electrode (1.3 mm diameter) was cleaned before self-assembled cysteamine monolayer modification. The gold surface was firstly polished with diamond and alumina slurry on silicon and microcloth pads, respectively (using Polishing Kit from BAS Inc, USA), and subsequently cleaned in deionized water with ultrasonic bath Enisonic 200 (Branson, The Netherland).

Experiments were performed in a $1 \mathrm{ml}$ cylindrical cell in room temperature. Measurements were carried out using square wave voltammetry (SWV) technique with following experimental conditions: frequency of $100 \mathrm{~Hz}$, amplitude of $0.04 \mathrm{~V}$ and step potential of $0.015 \mathrm{~V}$. Electrochemical response of $\mathrm{MB}$ were collected in the potential range from -0.40 to $+0.05 \mathrm{~V}$. All potentials were referred to $\mathrm{Ag} / \mathrm{AgCl}$ electrode.

Results of voltammetric experiments were presented using Origin software, version 6.0 (Microcal Software). Calculations were performed on the ground average from five measurements.

\subsection{Procedures}

\subsubsection{Immobilization of ssDNA probe on the modified gold electrode}

The self-assembled cysteamine monolayer (SAM) on gold surface was obtained by immersion of cleaned gold electrode (AuE) in freshly prepared $2.5 \mathrm{mM}$ water solution of cysteamine for 16 hours in room temperature. The SAM modified electrode (SAM/AuE) was rinsed with deionized water to remove physically adsorbed cysteamine and dried in air.

The immobilization of nucleic acid probe was carried out by immersion of SAM/AuE modified surface in the $50 \mathrm{mM}$ phosphate buffer solution (pH 7.0) containing $5 \mathrm{mM}$ EDC, $8 \mathrm{mM}$ NHS and 10 $\mu \mathrm{M}$ ssDNA ( $5 \mu \mathrm{M}$ in case of oligoG attachment) for a defined amount of time in room temperature, without stirring. After immobilization DNA modified gold electrode (ssDNA/SAM/AuE) was rinsed with $50 \mathrm{mM}$ phosphate buffer solution ( $\mathrm{pH}$ 7.0) before hybridization with target DNA. The procedure of ssDNA probe immobilization on the electrode surface was shown in figure 1.

\subsubsection{DNA hybridization}

The hybridization reaction was carried out by immersion a probe modified electrode (ssDNA/SAM/AuE) in $50 \mathrm{mM}$ phosphate buffer solution ( $\mathrm{pH} 7.4$ ) containing $0.5 \mathrm{M} \mathrm{NaCl}$ and denatured target DNA $(1.5 \mu \mathrm{g} / \mathrm{ml})$ for a defined amount of time in room temperature with stirring (200 rpm). Resulting DNA duplex modified electrode was rinsed with $50 \mathrm{mM}$ phosphate buffer (pH 7.0) for removing non-hybridized nucleic acid. The scheme of DNA hybridization on the electrode surface was shown in Fig. 1. The result of hybridization reaction was examined by methylene blue accumulation and measurement of the indicator electrochemical response.

The control experiments were performed in the same way using DNA isolated from non-GM soybean at the hybridization stage. 
Figure 1. Scheme of ssDNA probe immobilization and hybridization with target DNA (cDNA) on the gold electrode surface.
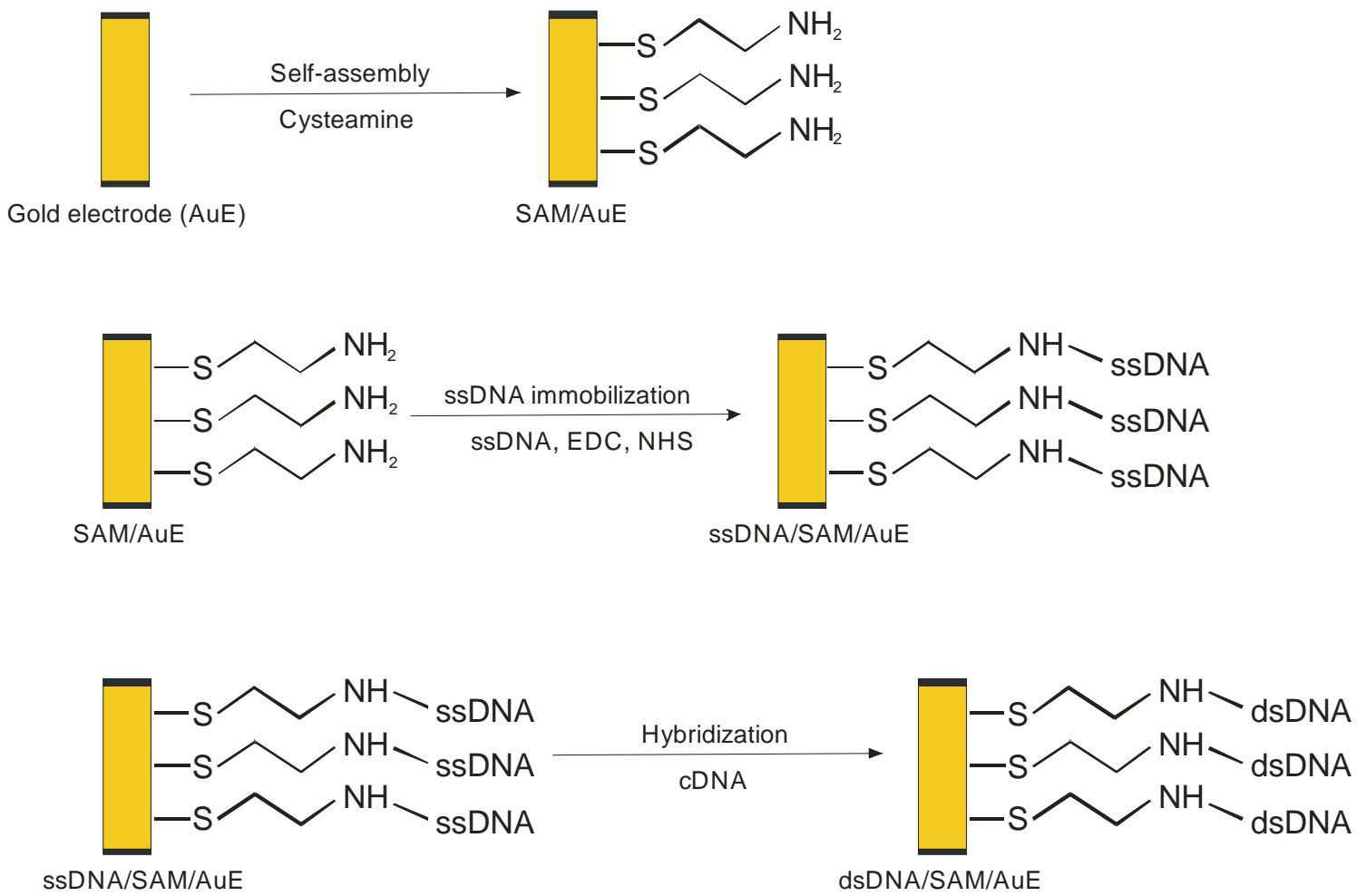

\subsubsection{MB accumulation and electrochemical measurement}

The results of gold electrode modification and also DNA hybridization was examined by measurement of electrochemical response of methylene blue accumulated on electrode surface. The electrode was immersed for 5 minutes with stirring $(200 \mathrm{rpm}$ ) in $50 \mathrm{mM}$ phosphate buffer (pH 7.0) solution containing $12.5 \mu \mathrm{M} \mathrm{MB}$ and $5 \mathrm{mM} \mathrm{KCl}$. In the next step the electrode was placed for 3 minutes in stirred indicator-free $50 \mathrm{mM}$ phosphate buffer ( $\mathrm{pH} 7.0$ ) with $5 \mathrm{mM} \mathrm{KCl}$ to remove unbound methylene blue compounds. The electrochemical response of accumulated indicator was measured after transfer the gold electrode to new cell with $50 \mathrm{mM}$ phosphate buffer solution containing $5 \mathrm{mM}$ $\mathrm{KCl}$.

\section{Results and Discussion}

\subsection{Optimization of a probe immobilization and hybridization procedures}

The electrochemical detection of specific nucleic acid sequences was based on hybridization with ssDNA probe immobilized on the electrode surface. The efficiency of hybridization event depended on the procedure of detection layer preparation (probe immobilization) and the conditions of its interaction with target DNA fragments. Steel et al. [29], Herne et al. [30] and also Peterson et al. [31] investigated the process of gold electrode modification with the thiol-derivatized oligonucleotides. In their studies the duration of electrode modification procedure played a very important role in biosensor 
performance. The same aspects were investigated in this work. The studies were carried out in order to check the relationship between the duration of electrode modification stages (probe immobilization and target DNA interaction) and hybridization efficiency. 19-mer homooligonucleotides of guanidine (oligoG) and cytidine (oligoC) were used as a ssDNA probe and target nucleic acid fragment, respectively. Such oligonucleotide combination enabled the highest diversification of affinity of methylene blue to single- and double-stranded oligonucleotides, based on the interaction between the indicator and guanine moieties. Oligonucleotides consisted of heterogeneous bases would have reduced diversification ability. In order to reduce spherical hindrance associated with arrangement of oligonucleotides on the electrode surface their length was additionally reduced to 19-mer in comparison with the length of the probes specific for $35 \mathrm{~S}$ promoter and nos terminator. Electrochemical detection of MB accumulated on the electrode surface modified with oligoG and after interaction with oligoC showed the results of a probe immobilization and nucleic acid hybridization.

Figure 2. Square wave $(\mathrm{SW})$ voltammograms of $\mathrm{MB}(12.5 \mu \mathrm{M})$ recorded on cysteamine SAM modified electrode after different time of oligoG probe immobilization (black line - 20 min, red - $60 \mathrm{~min}$, green $-120 \mathrm{~min}$, blue $-180 \mathrm{~min}$ ). SWV conditions: frequency of $100 \mathrm{~Hz}$, amplitude of $0.04 \mathrm{~V}$, step potential of $0.015 \mathrm{~V}$ in $50 \mathrm{mM}$ phosphate buffer $(\mathrm{pH} 7.0)$ containing $5 \mathrm{mM} \mathrm{KCl}$.

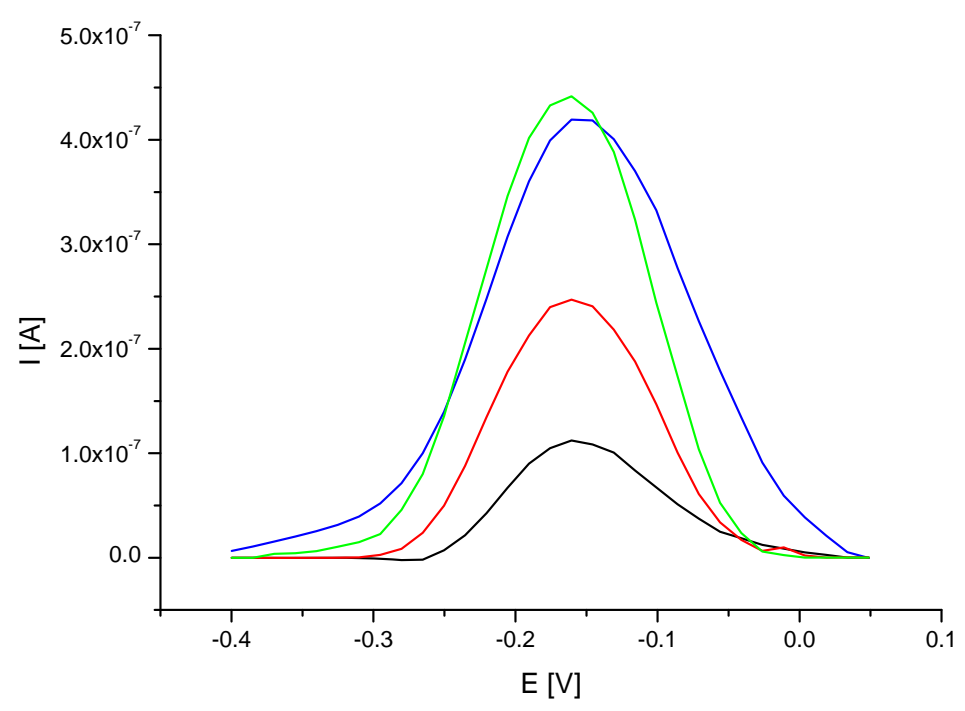

In the first experiment, the cysteamine SAM modified gold electrode was immersed in $50 \mathrm{mM}$ phosphate buffer ( $\mathrm{pH} 7.0$ ) containing $5 \mu \mathrm{M}$ oligoG, $5 \mathrm{mM}$ EDC and $8 \mathrm{mM}$ NHS for $20,60,120$ or 180 minutes, respectively. Figure 2 shows the square wave (SW) voltammograms of MB accumulated on the surface of cysteamine SAM/Au electrode modified with oligoG using different immobilization times. Increasing the immobilization time from 20 to 120 minutes led to higher amount of oligoG anchored on the electrode surface evidenced by higher rate of MB accumulation. Further prolongation of nucleotide immobilization time did not result in higher MB redox response, on the contrary, a decrease of methylene blue signal was found. The observed tendency is compatible with the results obtained during gold electrode modification with thiol-derivatized oligonucleotides [29-31]. After 
specific amount of time the further ssDNA immobilization did not led to increase of oligonucleotides bound on the electrode surface. The observed experiment outcome shows that the highest amount of ssDNA probe was attached to electrode surface after two hours immobilization.

The influence of oligonucleotide probe immobilization time on hybridization efficiency was also examined. The cysteamine SAM/Au electrode modified with oligoG (after 20, 60, 120 or 180 minutes of immobilization time) was immersed in $50 \mathrm{mM}$ phosphate buffer ( $\mathrm{pH} 7.4$ ) containing $5 \mu \mathrm{M}$ oligoC and $0.5 \mathrm{M} \mathrm{NaCl}$ for 1 hour (as described in the Materials and Methods). The results of hybridization reaction were monitored by electrochemical detection (SWV) of accumulated methylene blue (fig. 3.). The short time of oligoG probe immobilization and further interaction with oligoC led to high level of MB electrochemical response. The reason of relatively high methylene blue signal was probably the structure of electrode surface, which enabled higher adsorption rate of MB compounds in case of short oligoG immobilization time (20 or 60 minutes) and one hour hybridization with oligoC. Extending the oligoG immobilization time to 120 or 180 minutes resulted in higher surface density of accumulated ssDNA probe and changed the organization of electrode covering. After hybridization with oligoC the guanine moieties were less accessible for methylene blue and therefore its voltammetric signal decreased.

Figure 3. SW voltammograms of MB $(12.5 \mu \mathrm{M})$ on cysteamine SAM modified electrode after different time of oligoG probe immobilization (black line - $20 \mathrm{~min}$, red - $60 \mathrm{~min}$, green - 120 min, blue $-180 \mathrm{~min}$ ) and one hour hybridization with oligoC. SWV conditions as on Fig. 2.

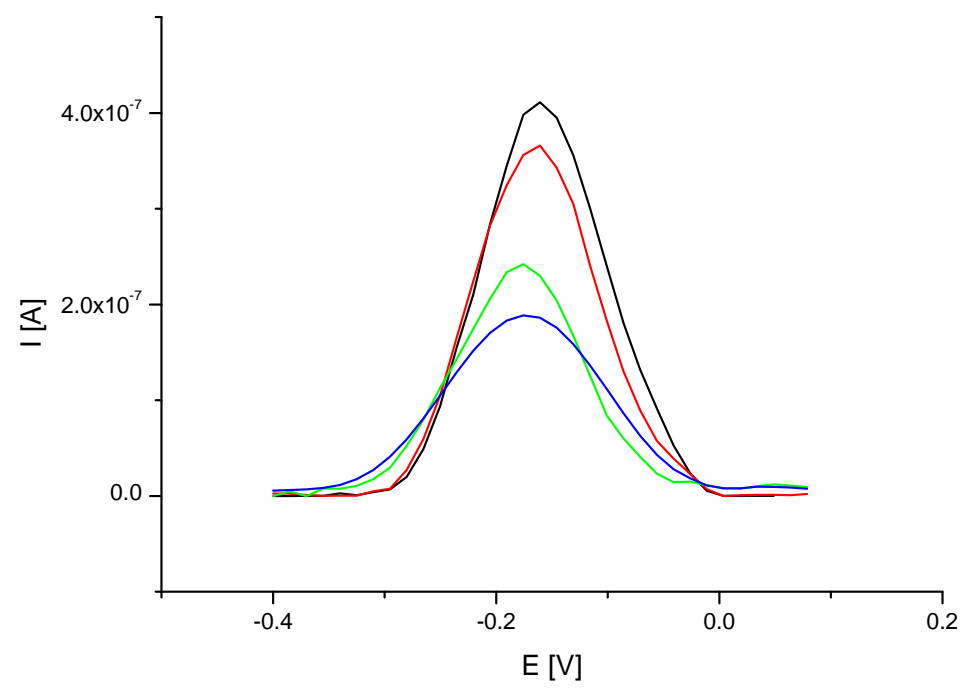

The mechanism of MB accumulation was also changing with the prolongation of oligoG anchoring procedure. At short immobilization time (20 or 60 minutes) dominating way of methylene blue collecting was its adsorption on electrode surface. On the other hand, prolonged time of probe immobilization (120 or 180 minutes) led to more efficient DNA duplex formation and increasingly important intercalation phenomena as a dominating mechanism of $\mathrm{MB}$ accumulation on electrode surface. The observed relationship was proved by moving MB peak to more negative potential typical 
for the intercalation of the methylene blue compounds in DNA duplex structure, what was previously investigated by Tani et al. [46].

Figure 4. Signal of MB accumulated on the gold electrode modified with oligoG (red line) and after one hour of hybridization with oligoC (green line) in case of different probe immobilization time. The MB response for dsDNA/SAM/Au electrode was subtracted from MB peak values for ssDNA/SAM/Au electrode (blue line). SWV conditions as on Fig. 2.

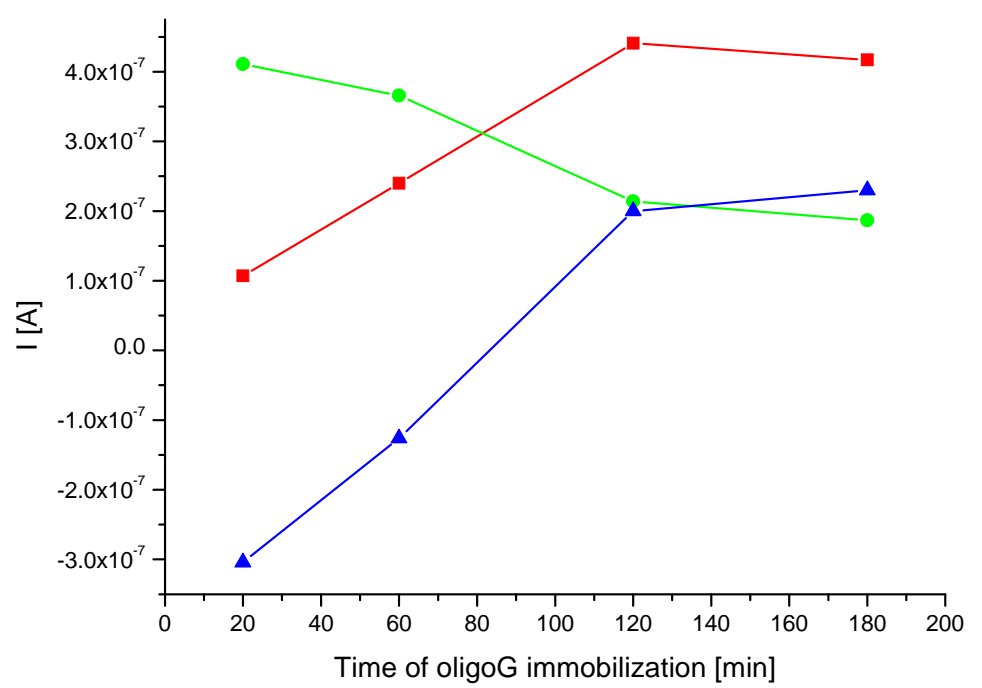

Methylene blue strong interacts with guanine, that is more accessible in ssDNA than dsDNA strands. The dye - base interaction enhances more effectively indicator accumulation on DNA modified electrode surface than intercalation of MB compounds into nucleic acid duplex structure. Therefore results of the hybridization reaction could be identified on the basis of higher MB affinity to single-stranded nucleic acid than DNA duplexes. Such approach was exploited both on carbon paste [42-44] and gold electrodes $[17,38]$. The main goal in the biosensor preparation procedure is to obtain maximal difference of indicator response between signals of the ss- and dsDNA modified electrodes. Appropriate duration of a probe immobilization and hybridization reaction could enhance this difference. Figure 4 shows the average MB signal observed on single- and double-stranded DNA modified electrodes depending of different immobilization times. The satisfying change in MB signal was obtained for the procedures including two and three hours of ssDNA probe immobilization time $(0.20 \mu \mathrm{A}$ and $0.23 \mu \mathrm{A}$, respectively) and one hour of hybridization with target DNA. Owing to time saving and lower probability of non-specific nucleic acid attachment (taking into account further experiments with the samples of isolated DNA) on the electrode surface for the next investigations the first procedure was chosen.

The influence of DNA hybridization reaction time on the results of interaction between the probe and target DNA fragment was also checked. Modified gold electrode with immobilized oligoG strands was immersed in $50 \mathrm{mM}$ phosphate buffer $(\mathrm{pH}$ 7.4) containing $5 \mu \mathrm{M}$ oligoC and $0.5 \mathrm{M} \mathrm{NaCl}$ for examined amount of hybridization time (from 15 to 90 minutes). Figure 5 presents the average MB peak heights (horizontal bars) and its standard deviations (vertical bars) from five measurements 
obtained on dsDNA/SAM/Au electrodes after different hybridization time. Extending the duration of hybridization to 75 minutes provided increasingly lower MB peak height (higher rate of DNA duplex formation). On the other hand such long time of interaction between the probe and target nucleic acid fragments led to poor repeatability of obtained square wave voltammograms results. Much better (lower) standard deviations and only a little higher average MB signal was achieved for hybridization reaction lasting one hour.

It was concluded from presented experiments that both duration of ssDNA probe immobilization and hybridization reaction significantly influenced the density of detection layer and the effectiveness of DNA duplex formation on the electrode surface. The obtained outcome correspond to with the results of the study on the thiol-derivatized oligonucleotides immobilization on gold surface [29-31]. Two hours of a probe covalent attachment and one hour of interaction with target DNA fragments was assumed as optimal and was used in further experiments focused on the examination of real samples of DNA (isolated from RoundupReady ${ }^{\circledR}$ and non-genetically modified soybean).

Figure 5. Average MB peak heights (horizontal bars) and its standard deviations (vertical bars) from five repeated measurements obtained on dsDNA/SAM/Au electrodes after different hybridization time (ranged from 15 to 90 minutes). SWV conditions as on Fig. 2.

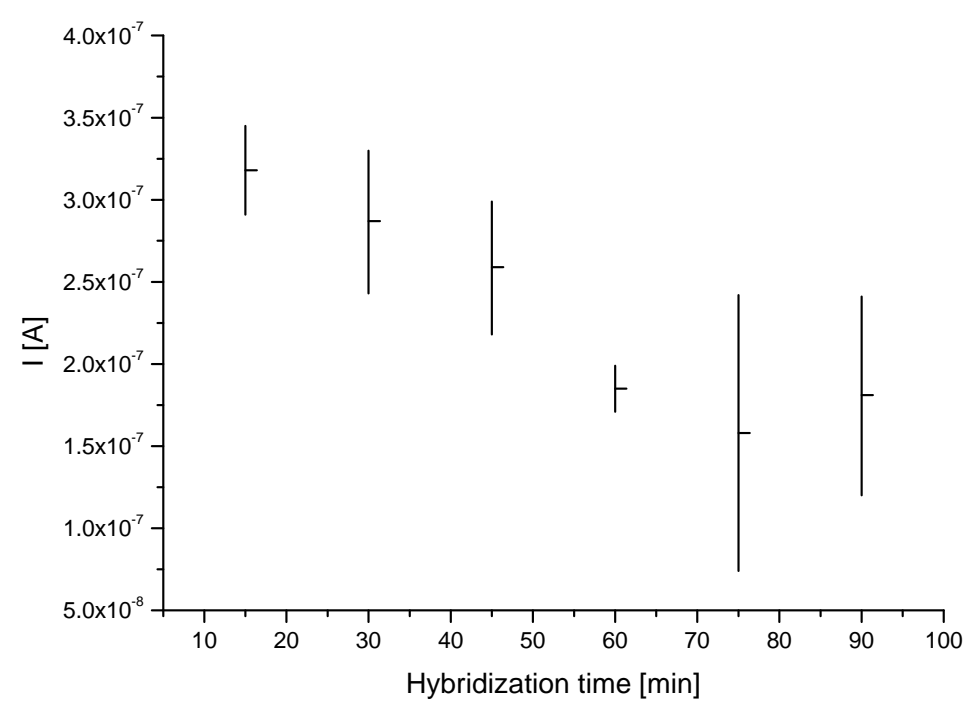

\subsection{Analytical approach based on electrochemical detection of 35 S promoter}

DNA hybridization biosensor was applied as a screening tool for the detection of genetic modification in soybean. Identification of DNA sample isolated from RoundupReady ${ }^{\circledR}$ was performed using a gold electrode modified with self-assembled cysteamine monolayer and ssDNA probe complementary to $35 \mathrm{~S}$ promoter. The preparation of biosensor detection layer was carried out as described in the Materials and Methods. ssDNA probe modified electrode was immersed in hybridization solution containing $1.5 \mu \mathrm{g} / \mathrm{ml}$ DNA isolated from RR soybean. Figure 6 demonstrates the SW voltammograms of MB accumulated on ssDNA probe modified electrode and after interaction 
with DNA isolated from RR and non-GM soybean, respectively. Additionally, table 1 shows experiments outcome for the five repeated measurements carried out at each examined analytical step.

Gold electrode modified with ssDNA probe specific for 35S promoter characterized high level of methylene blue accumulation due to its free access to guanine moieties. An average MB peak height on ssDNA/SAM/Au electrode reached $0.233 \mu \mathrm{A}$ (at the peak potential of $-0.160 \mathrm{~V}$ ). Hybridization reaction with DNA isolated from GM soybean led to five-fold reduction of methylene blue signal to $0.049 \mu \mathrm{A}$ (at the peak potential of $-0.176 \mathrm{~V}$ ). The decrease was caused by formation of DNA duplexes on electrode surface and limited access to guanine for indicator. The observed MB signal on dsDNA modified gold electrode was generally attributed to indicator compounds intercalated into DNA duplex structure. Additionally MB peak obtained on double-stranded DNA modified electrode was found at potential ca. $15 \mathrm{mV}$ more negative than that on ssDNA modified electrode. The mechanism of interaction between electroactive indicator and nucleic acid was different in case of single- and double-stranded DNA immobilized on the electrode surface and this was effected in the shift of methylene blue peak potential. Such observation was in agreement with the results of the investigation carried out by Tani et al. [46].

Figure 6. SW voltammograms of MB $(12.5 \mu \mathrm{M})$ on SAM/Au electrode modified with ssDNA probe specific for $35 \mathrm{~S}$ promoter before (black line) and after hybridization with DNA (1.5 $\mu \mathrm{g} / \mathrm{ml}$ ) isolated from RR (blue line) and non-genetically modified (red line) soybean. SWV conditions as on Fig. 2.

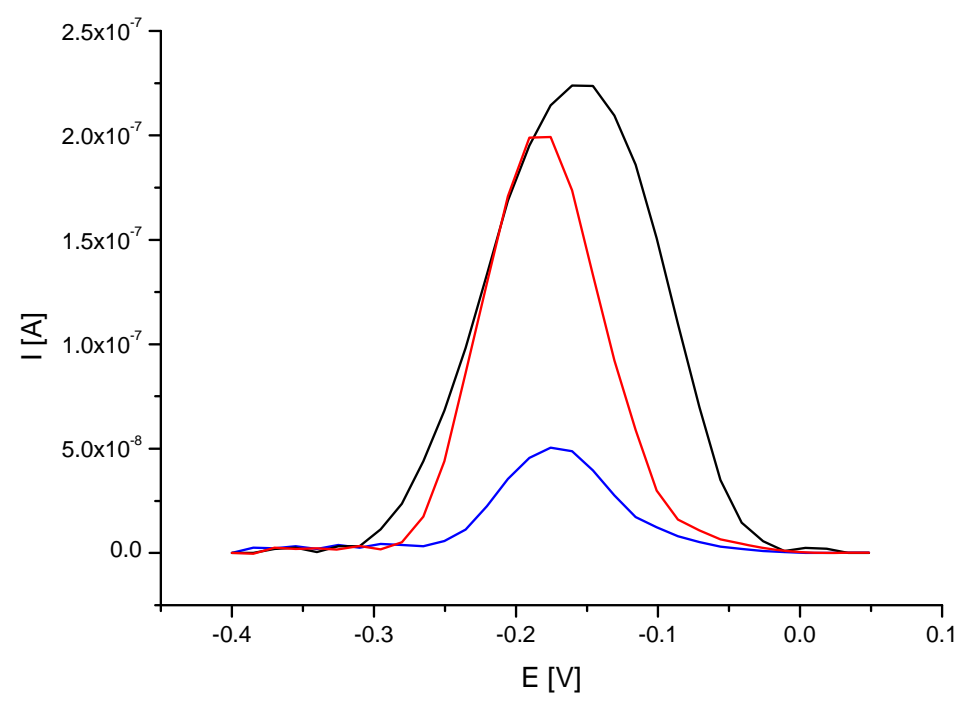

In reference examination with the use of DNA isolated from non-GM soybean MB signal was relatively high $(0.191 \mu \mathrm{A}$ at the peak potential of $-0.176 \mathrm{~V})$. The increase could have been explained by the failure of hybridization reaction and removing unbound soybean DNA from the electrode surface.

The experimental results obtained for ssDNA/SAM/Au electrode and after interaction with examined DNA samples show analytical potential of the biosensor for the detection of genetically modified food components. Series of five repetitive measurements for ssDNA probe, after 
hybridization with target DNA (from GM soybean), and after interaction with non-modified DNA resulted in satisfactory reproducible MB responses with relative standard deviation (RSD) of $16 \%$, $14 \%$ and $15 \%$ for MB peak height, and $4 \%, 6 \%$ and $4 \%$ for MB peak potential, respectively (table 1). The observed outcome was agreeable with the results of the investigations verifying methylene blue as a hybridization indicator, that was performed on carbon and gold electrodes [17, 38, 42-44]. Despite the RSD values of ca. 15\%, the distinct difference in MB response achieved with DNA isolated from $\mathrm{RR}$ and non-GM soybean provides convenient screening method for the presence of $35 \mathrm{~S}$ promoter sequence in analyzed DNA samples, that could indicate the presence of genetic modification.

Table 1. Peak current and potential of MB accumulated on gold electrode modified with ssDNA probe specific for $35 \mathrm{~S}$ promoter before and after hybridization with DNA isolated from RoundupReady ${ }^{\circledR}$ soybean and after hybridization with DNA from non-GM soybean.

\begin{tabular}{lcccc}
\hline \multicolumn{1}{c}{ Electrode } & $\begin{array}{c}\text { MB peak } \\
\text { current }[\mu \mathrm{A}]\end{array}$ & $\begin{array}{c}\text { RSD for MB } \\
\text { peak current } \\
\text { values [\%] }\end{array}$ & $\begin{array}{c}\text { MB peak } \\
\text { potential [V] }\end{array}$ & $\begin{array}{c}\text { RSD for MB } \\
\text { peak } \\
\text { potential [\%] }\end{array}$ \\
\hline $\begin{array}{l}\text { ssDNA/SAM/AuE specific for 35S } \\
\text { promoter }\end{array}$ & 0.233 & 16 & -0.160 & 4 \\
\hline $\begin{array}{l}\text { ssDNA/SAM/AuE after hybridization } \\
\text { with DNA from RR soybean }\end{array}$ & 0.049 & 14 & -0.176 & 6 \\
\hline $\begin{array}{l}\text { ssDNA/SAM/AuE after interaction } \\
\text { with DNA from non-GM soybean }\end{array}$ & 0.191 & 15 & -0.176 & 4 \\
\hline
\end{tabular}

\subsection{Analytical approach based on electrochemical detection of nos terminator}

The identification of DNA isolated from RoundupReady ${ }^{\circledR}$ soybean can be also performed by the detection of nucleic acid sequences specific for nos terminator. The procedure was very similar to the previous one, but the detection layer incorporated ssDNA probes complementary to examined terminator. Figure 7 provides methylene blue SW voltammograms observed on gold electrodes modified with oligonucleotide probe and after its interaction with DNA isolated from RR or non-GM soybean.

The average results of MB peak height and potential from five repeated measurements carried out on ssDNA/SAM/Au electrode before and after interaction with DNA of GM and non-GM soybean are presented in table 2. The immobilization of nucleic acid probe on the gold electrode surface caused high accumulation of methylene blue and its strong electrochemical response $(0.339 \mu \mathrm{A}$ at the peak potential of $-0.160 \mathrm{~V}$ ). Interaction between the probe and denatured DNA of RR soybean brought more than twofold decrease in indicator signal $(0.151 \mu \mathrm{A})$ and movement of the peak potential towards to more negative values (to the potential of $-0.176 \mathrm{~V}$ ). The tendency towards shifting of MB peak potential in case of single- and double-stranded DNA modified electrodes was the same as observed for the probe specific for $35 \mathrm{~S}$ promoter and similar to the outcomes of the investigation carried out by Tani et al. [46]. The obtained results suggested effective hybridization event and formation DNA 
duplex on the electrode surface. On the other hand interaction the probe with denatured DNA from non-GM soybean provided MB relatively high response $(0.351 \mu \mathrm{A})$, that was comparable with the results for ssDNA modified electrodes. The indicator signal proved a failure of hybridization event and poor attachment of soybean DNA to the electrode surface.

Figure 7. SW voltammograms of $\mathrm{MB}(12.5 \mu \mathrm{M})$ on SAM/Au electrode modified with ssDNA probe specific for nos terminator before (black line) and after hybridization with DNA (1.5 $\mu \mathrm{g} / \mathrm{ml}$ ) isolated from RR (blue line) and non-genetically modified (red line) soybean. SWV conditions as on Fig. 2.

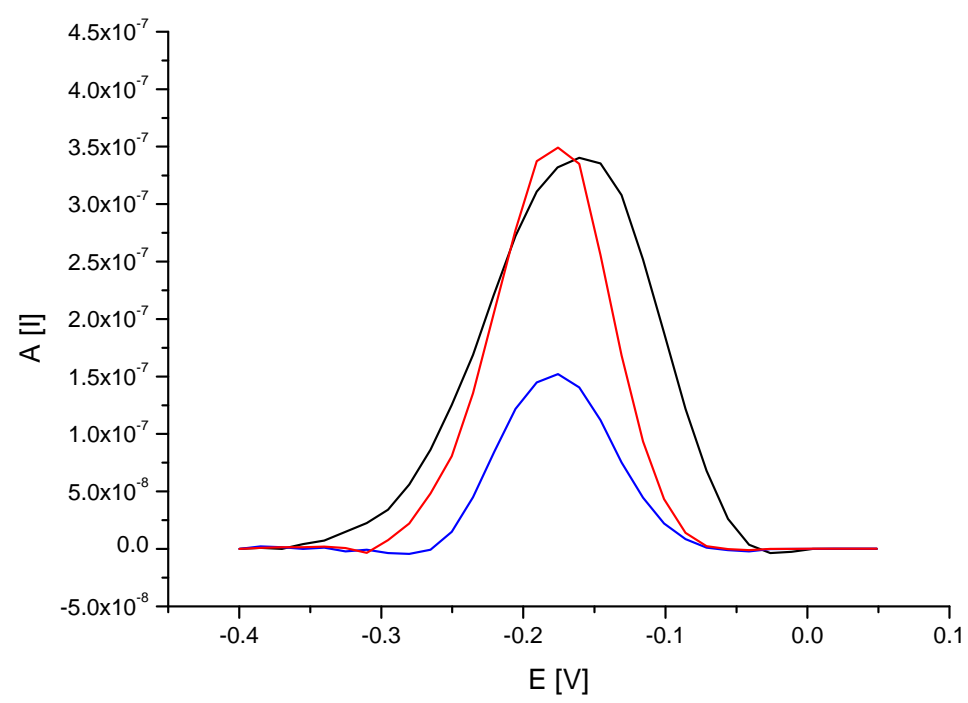

Series of five repetitive measurements for ssDNA probe, after hybridization with target genetically modified DNA, and after interaction with non-modified DNA resulted in reproducible MB responses with RSD of $6 \%, 5 \%$ and $7 \%$ for MB peak height, and $4 \%, 6 \%$ and $5 \%$ for MB peak potential, respectively (table 2). The behavior of $\mathrm{MB}$ compounds on the gold electrode surface modified with a single-stranded oligonucleotide probe, and after interaction with target or non-complementary DNA was comparable to the results observed in previously performed DNA hybridization investigations with methylene blue as an indicator [17, 38, 42-44]. Voltammetric detection of nos terminator with the use of methylene blue as the hybridization indicator was also reported by Meric et al [50]. The DNA samples used in hybridization step was extracted and amplified with PCR from commercially available products. After hybridization with target DNA, accumulation rate and signal value of MB decreased significantly in comparison with the probe signal. Hybridization did not occur after interaction with DNA sample form non-GM soybean, and the height of MB signal was found to be as high as a probe. The experiments in this work were carried out on the different electrode surface (gold), the probe (with another sequence) was immobilized covalently via self-assembled cysteamine monolayer and the detected DNA sequences were not amplified. Despite of the differences in biosensor performance the observed relation between MB signal obtained for probe, target DNA and reference material was similar to the results presented by Meric et al. [50]. Obtained significant difference in electrochemical response of $\mathrm{MB}$ in experiments with DNA isolated from both examined soybeans enabled an easy 
distinction of RR soybean from non-genetically modified soybean with the use of the investigated ssDNA probe specific for nos terminator. The second analytical approach also provided promising screening approach concerned on nos terminator detection and indication of the genetic modification in DNA samples without the use of PCR amplification.

Table 2. Peak current and potential of MB accumulated on gold electrode modified with ssDNA probe specific for nos terminator and after hybridization with DNA isolated from RoundupReady ${ }^{\circledR}$ soybean and after interaction with DNA from non-GM soybean.

\begin{tabular}{lcccc}
\hline \multicolumn{1}{c}{ Electrode } & $\begin{array}{c}\text { MB peak } \\
\text { current } \\
{[\mu \mathrm{A}]}\end{array}$ & $\begin{array}{c}\text { RSD for MB } \\
\text { peak current } \\
\text { values [\%] }\end{array}$ & $\begin{array}{c}\text { MB peak } \\
\text { potential } \\
{[\mathrm{V}]}\end{array}$ & $\begin{array}{c}\text { RSD for MB } \\
\text { peak } \\
\text { potential [\%] }\end{array}$ \\
\hline $\begin{array}{l}\text { ssDNA/SAM/AuE specific for nos } \\
\text { terminator }\end{array}$ & 0.339 & 6 & -0.160 & 4 \\
\hline $\begin{array}{l}\text { ssDNA/SAM/AuE after } \\
\text { hybridization with DNA from RR } \\
\text { soybean }\end{array}$ & 0.151 & 5 & -0.176 & 6 \\
\hline $\begin{array}{l}\text { ssDNA/SAM/AuE after interaction } \\
\text { with DNA from non-GM soybean }\end{array}$ & 0.351 & 7 & -0.176 & 5 \\
\hline
\end{tabular}

\section{Conclusions}

The main goal of the paper was the presentation of an electrochemical biosensor for DNA hybridization detection as a tool designed for screening of nucleic acid sequences typical for the genetically modified organisms. The main advancement of the analytical device was its simplicity with the satisfactory reliability of obtained results. Sensor presented in this work enabled convenient detection of $35 \mathrm{~S}$ promoter and nos terminator. Its analytical ability was demonstrated in successful differentiation of the DNA isolated from RoundupReady ${ }^{\circledR}$ soybean and non-genetically modified soybean. Both nucleic acid samples did not require any amplification procedure and were prepared with commercially available DNA isolation kit. The equivalent analytical results was obtain for the detection of both $35 \mathrm{~S}$ promoter and nos terminator. The examined nucleic acid sequences are present in wide variety of GMOs, therefore the biosensor could be adapted to the detection of other genetically modified food components made not only from GM soybean.

Additionally, the biosensor performance did not include the chemical (e.g. in piranha solution) or electrochemical (e.g. cyclic in defined potential range in slightly acidic solutions) electrode cleaning, which could have been more complex and time-consuming. In the context of obtained experimental results the DNA hybridization biosensor presented a strong potential to be used in screening of genetically modified food components. Established procedure provided promising features towards the development of very useful analytical tool. 


\section{References}

1. Wang, J.; Rivas, G.; Cai, X.; Palecek, E.; Nielsen, P.; Shiraishi, H.; Dontha, N.; Luo, D.; Parrado, C.; Chicharro, M.; Farias, P.A.M.; Valera, F.S.; Grant, D.H.; Ozsoz, M.; Flair, M.N. DNA electrochemical biosensors for environmental monitoring. A review. Anal. Chim. Acta 1997, 347, 1-8.

2. Marrazza, G.; Chianella, I.; Mascini, M. Disposable DNA electrochemical biosensors for environmental monitoring. Anal. Chim. Acta 1999, 387, 297-307.

3. Mascini, M.; Palchetti, I.; Marrazza, G. DNA electrochemical biosensors. Fresenius J. Anal. Chem. 2001, 361, 15-22.

4. Hall, R.H. Biosensor technologies for detecting microbiological foodborne hazards. Microbes Infect. 2002, 4, 425-432.

5. Palecek, E.; Jelen, F. Electrochemistry of Nucleic Acids and Development of DNA Sensors. Critical Rev. Anal. Chem. 2002, 32, 261-270.

6. Wang, J. In. Electroanalytical Methods for Biological Materials; Brajter-Toth, A.; Chambers, J.Q., Ed; Marcel Dekker, Inc.: New York, 2002, pp 27-42.

7. Drummond, T.G.; Hill, M.G.; Barton, J.K. Electrochemical DNA sensors. Nature Biotech. 2003, 21, 1192-1199.

8. de-los-Santos-Álvarez, P.; Lobo-Castañón, M.J.; Miranda-Ordieres, A.J.; Tuñón-Blanco, P. Electrochemistry of nucleic acids at solid electrodes and its applications. Electroanalysis 2004, 16, 1193-1204.

9. Bakker, E.; Qin, Y. Electrochemical sensors. Anal. Chem. 2006, 78, 3965-3983.

10. Minunni, M.; Tombelli, S.; Mariotti, E.; Mascini, M.; Mascini, M. Biosensors as new analytical tool for detection of Genetically Modified Organisms (GMOs). Fresenius J. Anal. Chem. 2001, $369,589-593$.

11. Marrazza, G.; Chianella, I.; Mascini, M. Disposable DNA electrochemical sensor for hybridization detection. Biosens. Bioelectron. 1999, 14, 43-51.

12. Pividori, M.I.; Merkoçi, A.; Alegret, S. Electrochemical genosensor design: immobilisation of oligonucleotides onto transducer surfaces and detection methods. Biosens. Bioelectron. 2000, 15, 291-303.

13. Wang, J. From DNA biosensors to gene chips. Survey and summary. Nucleic Acids Res. 2000, 28, 3011-3016.

14. Xu, Ch.; He, P.; Fang, Y. Electrochemical labeled DNA probe for the detection of sequencespecific DNA. Anal. Chim. Acta 2000, 411, 31-36.

15. Watterson, J.; Piunno, P.A.E.; Krull, U.J. Practical physical aspects of interfacial nucleic acid oligomer hybridisation for biosensor design. Anal. Chim. Acta 2002, 469, 115-127.

16. Kerman, K.; Kobayashi, M.; Tamiya, E. Recent trends in electrochemical DNA biosensor technology. Meas. Sci. Technol. 2004, 15, R1-R11.

17. Loaiza, Ó,A.; Campuzano, S.; López-Berlanga, M.; Pedrero, M.; Pingarrón, J.M. Development of a DNA Sensor Based on Alkanethiol Self-Assembled Monolayer-Modified Electrodes. Sensors 2005, 5, 344-363. 
18. Palecek, E.; Fojta, M. In. Bioelectronics; Willner, I., Katz, E., Ed.; WILEY-VCH Verlag GmbH \& Co, KGaA: Weinheim, 2005, pp 127-192.

19. Odenthal, K.J.; Gooding, J.J. An introduction to electrochemical DNA biosensors. Analyst 2007, 132, 603-610.

20. Luong, J.H.T.; Bouvrette, P.; Male, K.B. Developments and applications of biosensors in food analysis. TIBTECH 1997, 15, 369-377.

21. Wang, J. Towards Genoelectronics: Electrochemical Biosensing of DNA Hybridization. Chem. Eur. J. 1999, 5, 1681-1685.

22. Schmidt, A.; Bilitewski, U. In. Instrumentation and sensors in the food industry; Kress-Rogers, E.; Brimelov, C.J.B., Ed.; Woodhead Publishing Limited: Cambridge, 2001, pp 714-739.

23. Nakamura, H.; Karube, I. Current research activity in biosensors. Anal. Bioanal. Chem. 2003, 377, 446-468.

24. Elenis, D.S.; Kalogianni, D.P.; Glynou, K.; Ioannou, P.C.; Christopoulos, T.K. Advances in molecular techniques for the detection and quantification of genetically modified organisms. Anal. Bioanal. Chem. 2008, Epublished ahead of print.

25 Hahn, S.; Mergenthaler, S.; Zimmermann, B.; Holzgreve, W. Nucleic acid based biosensors: The desires of the user. Bioelectrochemistry 2005, 67, 151-154.

26. Wang, J. Electrochemical nucleic acid biosensors. Anal. Chim. Acta 2002, 469, 63-71.

27. de-los-Santos-Álvarez, P.; Lobo-Castañón, M.J.; Miranda-Ordieres, A.J.; Tuñón-Blanco, P. Current strategies for electrochemical detection of DNA with solid electrodes. Anal. Bioanal. Chem. 2004, 378, 104-118.

28. Chiorcea Paquim, A.-M.; Diculescu, V.C.; Oretskaya, T.S.; Oliveira Brett, A.M. AFM and electrochemical studies of synthetic oligonucleotide hybridization. Biosens. Bioelectron. 2004, 20, 933-944.

29. Steel, A.B.; Herne, T.M.; Tarlov, M.J. Electrochemical Quantitation of DNA Immobilized on Gold. Anal. Chem. 1998, 70, 4670-4677.

30. Herne, T.M.; Tarlov, M.J. Characterization of DNA Probes Immobilized on Gold Surfaces. J. Am. Chem. Soc. 1997, 119, 8916-8920.

31. Peterson, A.W.; Heaton, R.J.; Georgiadis, R.M. The effect of surface probe density on DNA hybridization. Nucleic Acids Res. 2001, 29, 5163-5168.

32. Sun, X.; He, P.; Liu, Sh.; Ye, J.; Fang, Y. Immobilization of single-stranded deoxyribonucleic acid on gold electrode with self-assembled aminoethanethiol monolayer for DNA electrochemical sensor applications. Talanta 1998, 47, 487-495.

33. Lucarrelli, F.; Marrazza, G.; Turner, A.P.F.; Mascini, M. Carbon and gold electrodes as electrochemical transducers for DNA hybridisation sensors. Biosens. Bioelectron. 2004, 19, 515530 .

34. Yang, M.; McGovern, M.E.; Thompson, M. Genosensor technology and the detection of interfacial nucleic acid chemistry. Anal. Chim. Acta 1997, 346, 259-275.

35. Zhao, Y.D.; Pang, D.W.; Hu, S.; Wang, Z.L.; Cheng, J.K.; Dai, H.P. DNA-modified electrodes; part 4: optimization of covalent immobilization of DNA on self-assembled monolayers. Talanta 1999, 49, 751-756. 
36. Chaki, N.K.; Vijayamohanan, K. Self-assembled monolayers as a tunable platform for biosensor applications. Biosens. Bioelectron. 2002, 17, 1-12.

37. Carvalhal, R.F.; Freire, R.S.; Kubota, L.T. Polycrystalline Gold Electrodes: A Comparative Study of Pretreatment Procedures Used for Cleaning and Thiol Self-Assembly Monolayer Formation. Electroanalysis 2005, 17, 1251-1259.

38. Kerman, K.; Ozkan, D.; Kara, P.; Meric, B.; Gooding, J.J.; Ozsoz, M. Voltammetric determination of DNA hybridization using methylene blue and self-assembled alkanethiol monolayer on gold electrodes. Anal. Chim. Acta 2002, 462, 39-47.

39. Smith, R.K.; Lewis, P.A.; Weiss, P.S. Patterning self-assembled monolayers. Prog. Surf. Science 2004, 75, 1-68.

40. Palecek, E.; Fojta, M.; Tomschik, M.; Wang, J. Electrochemical biosensor for DNA hybridization and DNA damage. Biosens. Bioelectron. 1998, 13, 621-628.

41. Mishima, Y.; Motonaka, J.; Ikeda, S. Utilization of an osmium complex as a sequence recognizing material for DNA-immobilized electrochemical sensor. Anal. Chim. Acta 1997, 345, 45-50.

42. Erdem, A.; Kerman, K.; Meric, B.; Akarca, U.S.; Ozsoz, M. Novel hybridization indicator methylene blue for the electrochemical detection of short DNA sequences related to the hepatitis B virus. Anal. Chim. Acta 2000, 422, 139-149.

43. Ozkan, D.; Kara, P.; Kerman, K.; Meric, B.; Erdem, A.; Jelen, F.; Nielsen, P.E.; Ozsoz, M. DNA and PNA sensing on mercury and carbon electrodes by using methylene blue as an electrochemical label. Bioelectrochemistry 2002, 58, 119-126.

44. Erdem, A.; Kerman, K.; Meric, B.; Ozsoz, M. Methylene Blue as a Novel Electrochemical Hybridization Indicator. Electroanalysis 2001, 13, 219-223.

45. Yang, W.; Ozsoz, M.; Hibbert, D.B.; Gooding, J.J. Evidence for the Direct Interaction Between Methylene Blue and Guanine Bases Using DNA-Modified Carbon Paste Electrodes. Electroanalysis 2002, 14, 1299-1302.

46. Tani, A.; Thomson, A.J.; Butt, J.N. Methylene blue as an electrochemical discriminator of singleor double-stranded oligonucleotides immobilised on gold substrates. Analyst 2001, 126, 17561759.

47. MacCornik, C.A.; Griffin, H.G.; Underwood, H.M.; Gasson, M.J. Common DNA sequences with potential of genetically manipulated organisms in food. J. Appl. Microbiol. 1998, 84, 969-980.

48. Anklam, E.; Gadani, F.; Heinze, P.; Pijnenburg, H.; Van Den Ende, G. Analytical methods for detection and determination of genetically modified organisms in agricultural crops and plantderived food products. Eur. Food Res. Technol. 2002, 214, 3-26.

49. Querci, M.; Maretti, M.; Mazzara, M. Qualitative Detection of MON810 Maize, Bt-176 Maize and Roundup Ready ${ }^{\circledR}$ Soybean by PCR, in. The Analysis of Food Samples for the Presence of Genetically Modified Organisms; Querci, M., Jermini, M., Van den Eede, G., Ed.; European Communities, Luxemburg, 2006, Session 9.

50. Meric, B.; Kerman, K.; Marrazza, G.; Palchetti, I.; Mascini, M.; Ozsoz, M. Disposable genosensor, a new tool for the detection of NOS-terminator, a genetic element present in GMOs. Food Control 2004, 15, 621-626.

51. Mariotti, E.; Minunni, M.; Mascini, M. Surface plasmon resonance biosensor for genetically modified organisms detection. Anal. Chim. Acta 2002, 453, 165-172. 
52. Wang, R.; Tombelli, S.; Minunni, M.; Spiriti, M.M.; Mascini, M. Immobilisation of DNA probes for the development of SPR-based sensing. Biosens. Bioelectron. 2004, 20, 967-974.

53. Kalogianni, D.P.; Koraki, T.; Christopoulos, T.K.; Ioannou, P.C. Nanoparticicle-based DNA biosensor for visual detection of genetically modified organisms. Biosens. Bioelectron. 2006, 21, 1069-1076.

54. Passamano, M.; Pighini, M. QCM DNA-sensor for GMOs detection. Sens. Act. B 2006, 118, 177 181.

55. Stobiecka, M.; Cieśla, J.M.; Janowska, B.; Tudek, B.; Radecka, H. Piezoelectric Sensor for Determination of Genetically Modified Soybean Roundup Ready® in Samples not Amplified by PCR. Sensors 2007, 7, 1462-1479.

56. Carpini, G.; Lucarelli, F.; Marrazza, G.; Mascini, M. Oligonucleotide-modified screen-printed gold electrodes for enzyme-amplified sensing of nucleic acids. Biosens. Bioelectron. 2004, 20, 167-175.

57. Lucarelli, F.; Marrazza, G.; Mascini, M. Enzyme-based impedimetric detection of PCR products using oligonucleotide-modified screen-printed gold electrodes. Biosens. Bioelectron. 2005, 20, 2001-2009.

(C) 2008 by MDPI (http://www.mdpi.org). Reproduction is permitted for noncommercial purposes. 